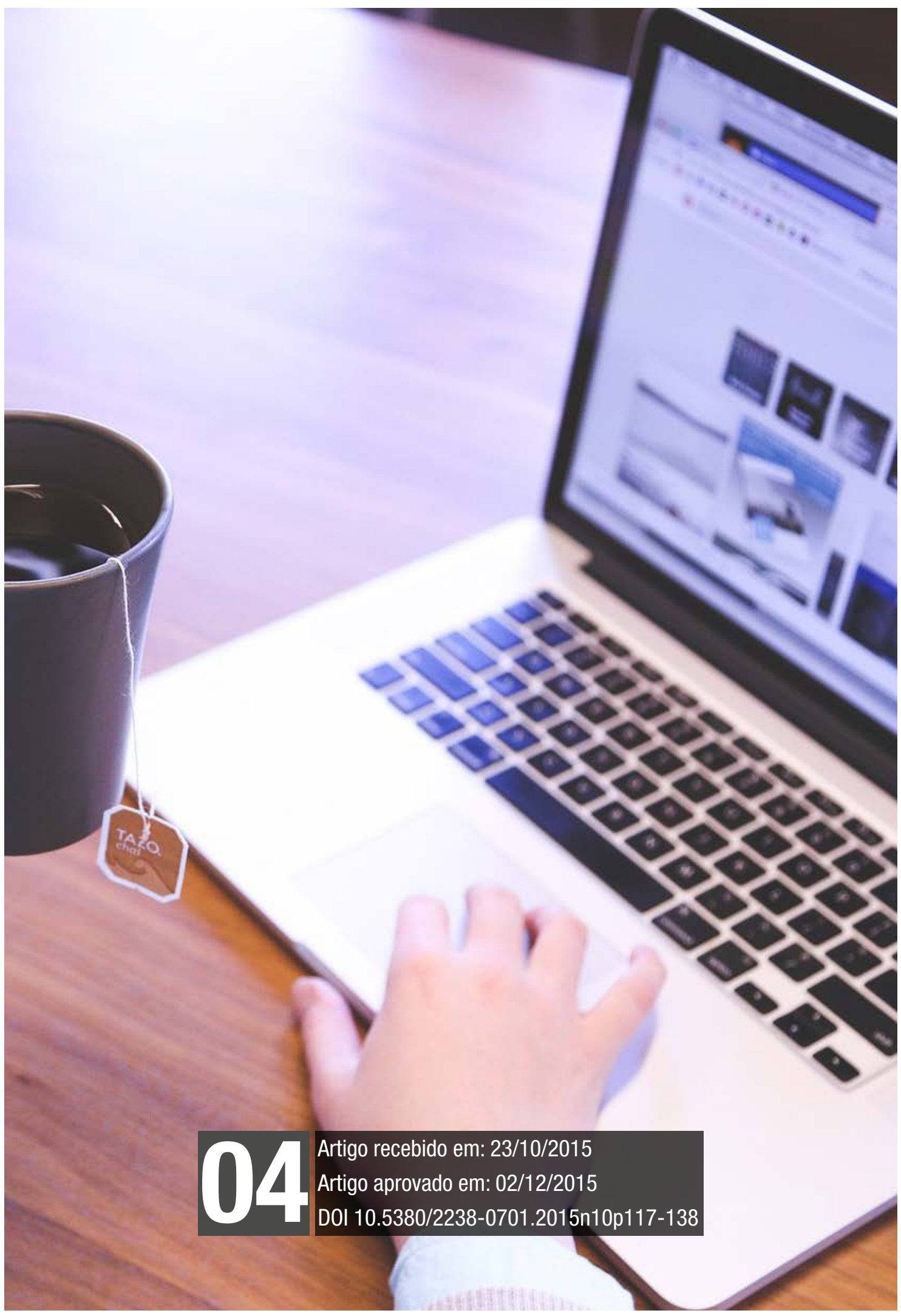


AÇÃO MIDIÁTICA, n. 10. Ju/Dez. 2015. Curitiba. PPGCOM-UFPR. ISSN 2238-0701 


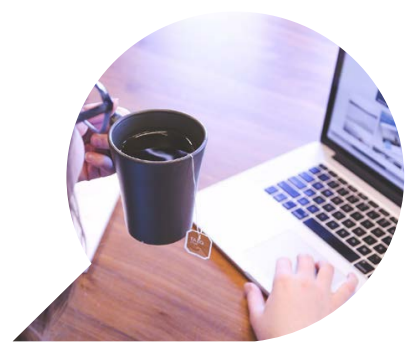

\title{
O que as imagens do jornalismo fazem ver: estratégias discursivas do Brasil Post
}

\author{
What journalism images make us see: discursive \\ strategies of Brasil Post
}
Qué las imágenes de periodismo nos hacen ver: las estrategias discursivas de Brasil Post

\begin{tabular}{l}
\hline KATI CAETANO * $^{*}$ \\
\hline ZACLIS VEIGA $^{* *}$
\end{tabular}

Resumo: Fundamentado em teorias que tratam de estratégias discursivas verbovisuais, este artigo tem como objeto de análise a versão brasileira do webjornal Huffington Post, Brasil Post, veiculado sob a tutela da Editora Abril, e visa a refletir sobre alguns aspectos que configuram a estrutura e apresentação das imagens veiculadas nesses webjornais. $\mathrm{O}$ recorte, feito em dois períodos, novembro de 2014 e janeiro de 2015, apresentou relações de complementaridade de diversas ordens, o que per-

\footnotetext{
* Doutora em Letras pela Universidade de São Paulo (FFLCH/USP); pós-doutora em Semiótica (CNRS/France) e em Ciências da Linguagem (Université de Paris 7). Professora titular e pesquisadora vinculada ao Programa de Pós-Graduação em Comunicação e Linguagens PPGCom/UTP; líder do Grupo de Pesquisa "Interações Comunicacionais, Imagens e Culturas Digitais - INCOM/CNPq.

** Doutora em Ciência da Informação pela Universidade Fernando Pessoa, Mestre em Multimeios pela UNICAMP, Bacharel em Jornalismo pela UEPG. Professora Titular e coordenadora do curso de Jornalismo da Universidade Positivo.
} 
mitiu o estabelecimento de uma pequena tipologia de instâncias de mediação de sentidos. Sendo assim, este artigo, além de contribuir para a expansão do senso crítico relacionado às fotografias transmitidas na web, poderá, também, cooperar com investigações voltadas à análise de imagens ancoradas em produtos jornalísticos da internet.

Palavras-chave: Webjornalismo; Fotografia; Relações verbovisuais; Brasil Post.

Abstract: Based upon theories that address the verbovisual discursive strategies of the text-image, this article is a frame of the online Brazilian journal version Huffington Post, Brasil Post, served under the tutelage of Editora Abril and aims to observe and determine questions about some points orbiting the structure and presentation of the images conveyed in online journals. The frame, made in two periods, November 2014 and January 2015, introduced complementary relations of various degrees, which enabled the establishment of a small type instances. This article, in addition to contributing to the expansion of critical thinking related to pictures transmitted on the web can also cooperate with investigations, which frames are photos anchored in journalistic products of the internet.

Keywords: Web journalism; Photography; Verbo-visual relations, Brasil Post.

Resumen: Fundamentado en las teorías que tratan de estrategias discursivas verbovisuales, este artículo tiene como objeto de análisis la versión brasileña del periódico en línea Huffington Post - Brasil Post - emitido bajo la tutela de la Editora Abril y su objetivo es reflejar sobre algunos aspectos que configuran la estructura y presentación de las imágenes presentes en estos sitios de noticias. El recorte, hecho en dos períodos, de noviembre de 2014 y enero de 2015, introdujo relaciones complementarias de diversos órdenes, lo que permitió el establecimiento de una pequeña tipología de instancias de mediación de sentidos. Este artículo, además de contribuir a la expansión del pensamiento crítico en relación con las imágenes transmitidas en la web, puede también cooperar con investigaciones dirigidas al estudio de fotografías ancladas en productos periodísticos de la Internet. visuales; Brasil Post. 


\section{Fazer ver}

A escolha do mote deste artigo - o que as imagens do jornalismo fazem ver - tem como ponto de partida nossa participação na pesquisa em rede Brasil/França/Líbano/Canadá sobre as chamadas novas práticas jornalísticas ${ }^{1}$. Embora se tenha discorrido prodigamente sobre o papel das imagens, seja no jornalismo, ou fora dele no curso da vida cotidiana, o princípio que nos move é de compreendê-las no quadro de uma investigação específica, o de acompanhamento e análise do webjornal Brasil Post (BP), selecionado como parte preliminar de um estudo mais amplo.

O primeiro ponto a se deixar claro é que não concebemos as imagens em si mesmas, como formas isoladas capazes de sustentar o sistema informativo gerado no quadro de uma edição ou de um conjunto de periódicos de um mesmo jornal. Embora tenham (algumas mais do que outras) valores simbólicos autossuficientes para originar sentidos, em não raras oportunidades de modo mais intenso do que uma matéria verbal, as imagens ganham significações na moldura do jornal, em seu jogo verbovisuais, de discursos verbais, de composição, de oposições, de topologias na superfície da página/tela, de valorizações cromáticas e eidéticas. Será, portanto, nesse sentido que as estratégias discursivas do jogo texto-imagem serão abordadas no presente artigo.

A respeito do emprego do termo "estratégias" cabe igualmente uma explicação: em geral, esse vocábulo evoca uma intencionalidade, uma manobra de planejamento voltada a dirigir uma ação ou uma interpretação. Adotamos, porém, um sentido mais amplo para o conceito; a intencionalidade aqui não se manifesta como um previsão de caminhos, mas a direcionalidade de um percurso que pode se desenvolver por meio de procedimentos conscientes, inconscientes e surgidos também em ato, o que inscreve o discurso numa espécie de navegação à deriva. Tal fato fica mais evidente no circuito informativo do espaço digital, sobretudo em sua compleição contemporânea, de formas colaborativas (seja qual for o sentido que se atribua a essa noção, como participação efetiva ou regulada do leitor na produção

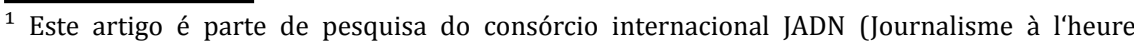
du numérique) formado pela Université Lumière Lyon 2, Universidade Federal do Paraná, Universidade Positivo, Universidade Tuiuti do Paraná, Université Antoine, le centre Max Weber e Grupo de Pesquisa Click, abarcando pesquisas do Brasil, França, Líbano e Canadá. Pode ser visualizado no endereço: jadn.univ-lyon2.fr
} 
da notícia), quando as possibilidades de mudanças axiológicas na valorização de uma pauta, de uma postura do jornal, de divulgação de um fato, tomam rumos surpreendentes que escapam ao planejamento de agendas prévias ou de expectativas dos editores jornalísticos.

Explicitemos, portanto, que as estratégias engendram tanto ações projetadas quanto ações surgidas ao acaso, no processo de recepção e interação com o jornal, em relações fortuitas com outras formas midiáticas, ou mesmo como operações do sistema gerenciadas por softwares, que dão primazia a certos fatores em detrimento de outros com base em complexo jogo de análise de base de dados. No entanto, o movimento reiterado como um periódico se apresenta, mesmo nas suas possibilidades interativas casuais, permite afirmar que as estratégias constituem o(s) modo(s) como um jornal se apresenta regularmente, em certo intervalo de tempo, configurando aos olhos do leitor um estilo com o qual adquire familiaridade e agilização de manuseio (busca/leitura). Adquire, assim, uma espécie de identidade visual (FLOCH, 1995) e ideológica a despeito das metamorfoses que sofre, das contradições que expõe, e dos ajustamentos (LANDOWSKI, $2005 \mathrm{a}, 2005 \mathrm{~b}$ ) que processa visando à permanente atenção de leitores.

Nesse campo de princípios com os quais lidamos para adentrar a análise das imagens, afigura-se ainda relevante o fato de que boa parte das imagens examinadas, em dois períodos de tempo de rastreamento (novembro de 2014/janeiro de 2015), não apresentam os créditos de autoria. Se o apresentam numa primeira exibição, nas subsequentes em outras seções do jornal elas são apagadas. Essa atitude é reveladora de um aspecto característico do jornalismo digital, o de apropriação de dados do sistema sem fundo da internet, colocando as agências de notícias não como o principal provedor de informação, mas como um sistema paralelo. A essas duas rotinas se somam ainda as colaborações dos leitores, em geral graciosamente disponibilizadas pelo simples fato de valorização que adquirem com sua visibilidade pública, independente da creditação expressa do operador da fotografia. Expõe-se desse modo um modo de ver as imagens fotográficas ainda segundo o pressuposto de seu rastro de indicialidade, às quais se aderem traços de um fazer verdadeiro. O procedimento já é bem conhecido no jornalismo, antes ainda de sua inserção no mercado e na cultura digital ${ }^{2}$, mas deixa evidente no

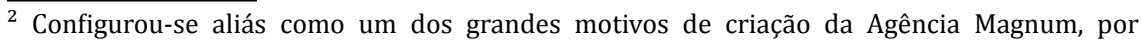


novo contexto em que vivemos tanto a lógica do jornalismo base de dados, quanto a ideia de que a voz da imagem aparece como o próprio fato se enunciando, à revelia de um olhar, de uma captura, de uma escolha e de uma composição. Esse aspecto será fundamental para os comentários finais, quando será lido à luz de outras características depreendidas pela análise.

Feitas tais considerações, entendemos que é necessário empreender um recorte de partida para abarcar o corpus levantado, e, para tanto, buscaremos apoio em um texto seminal das teorias da imagem, o artigo de Barthes (1964, p. 40-51) sobre dois modos de compartilhamento texto-imagem, quais sejam o de ancoragem e o de etapa, com alguns ajustes ao raciocínio trabalhado no presente artigo. Entendemos que a função de ancoragem pressupõe uma articulação entre ambas as linguagens de mera tautologia - o que se fala está mostrado visualmente. No jornalismo, essa função é comum porque o verbal permite reduzir a polissemia da imagem. Apesar da obviedade dessa definição, ela encerra implicações simbólicas importantes, porque aciona mecanismos de fazer crer baseados na transparência da imagem, muitas vezes confundida com o papel de representação de um suposto real mobilizado pela fotografia.

Cabe outro esclarecimento neste ponto, o de nossa concepção da relação imagem-realidade. Antes que formas representativas, de tentativa de reprodução do real, as formas simbólicas, mesmo a fotografia em sua produção analógica como "grafia da luz", consistem em constructos amparados em modos de conceber o mundo que variam histórica e culturalmente, e dos quais derivam formalizações visuais destinadas a dar a impressão de uma visão do real tal qual se imagina (FLOCH, 1986 ; GREIMAS \& COURTÉS, 1979, verbetes: imagem p. 226; referente - p. 377-379; veridicção - p. 485-487). Em face de suas visualizações, no entanto, não se tem propriamente uma representação do real, e sim uma forma de reconhecimento (FONTANILLE, 2005, p. 99-122) daquilo que conceitualmente se estabelece como o real. Exemplos reiterados como o perspectivismo renascentista e a sua desconstrução pelos movimentos vanguardistas do final do século XIX e início do século XX são normalmente citados como deslocamentos das maneiras de tentar-se representar visões diferentes da

fotógrafos empenhados em valorizar seu processo e produto de trabalho, entre eles Robert Capa, David Seymour e Henry-Cartier Bresson, em meados do século XX. 
realidade, e em suma de fazer realismo, que não a define mais como algo fixo, imutável e definitivamente dado.

As relações de ancoragem equivalem, desde esse ponto de vista, a processos de reconhecimento de um pretenso real promovido pelas fotografias. Não há nenhum acréscimo de valor simbólico nelas, a não ser o de efeito de sentido de realidade, como impressão de verdadeiro. Sabemos, claro, que a par dessa função, o papel de atrativos do olhar sobre a superfície de manchas cinzas de texto é fundamental. Atendem assim a uma demanda de caráter mercadológico, na busca insistente e tradicional de chamar a atenção e causar sensação, como maneira de se fazer distinguir e serem percebidas (TÜRCKE, 2010).

O sociólogo alemão Christophe Türcke vai conferir a esse procedimento a marca de uma sociedade baseada nas sensações, definindo estas últimas, em seu sentido redutor assumido desde o esquema da sociedade concorrencial iniciada na Renascença, como percepções àquilo que causa sensação, ao sensacional, e que se manifesta em toda a sua evidência tardiamente no nosso aparelho sensorial com a sociedade da microeletrônica (TÜRCKE, 2010). No âmbito desse princípio norteador é que parece se justificar outra característica das imagens na diagramação da página na tela: elas compõem pequenos blocos (boxes) multicoloridos dispostos em alinhamento horizontal em três laudas, correspondentes a três seções diferentes do BP (blogs, editoriais e notícias, informações, e as seções "bombando" ou "mais bombadas" da semana), e em disposição vertical, compondo eixos de ortogonalidade que subsumem as chamadas para as matérias textuais, encabeçadas por um título, legenda, teaser ou micro-manchete.

A configuração visual é de imagens alinhavadas por fios de textos que vão emergindo no processo de rolagem da página. Tal diagramação está assinalada pelo design vertical de surgimento dos dados, característico do jornalismo online, em telas, e já presente no impresso. A diferença é que neste o layout aparece de uma mirada, como ação terminada e pronta a ser vista, enquanto naquele o desenho de notícias que vão sendo atualizadas na medida mesma de emergência da superfície oculta da página confere o efeito de sentido de informação em construção, numa evidente relação tautológica com o princípio norteador do online que é a promessa da informação em tempo real. Visto desse modo, o encabeçamento de todas as matérias dado pelos blocos de imagens outorga às fotografias um papel proeminente, de princípio direcionador da informação lida. Elas não ilustram simples- 
mente o verbal, mas o direcionam, o subsumem, o antecipam e valorizam o conteúdo que virá destrinchado pelo que nelas está prometido.

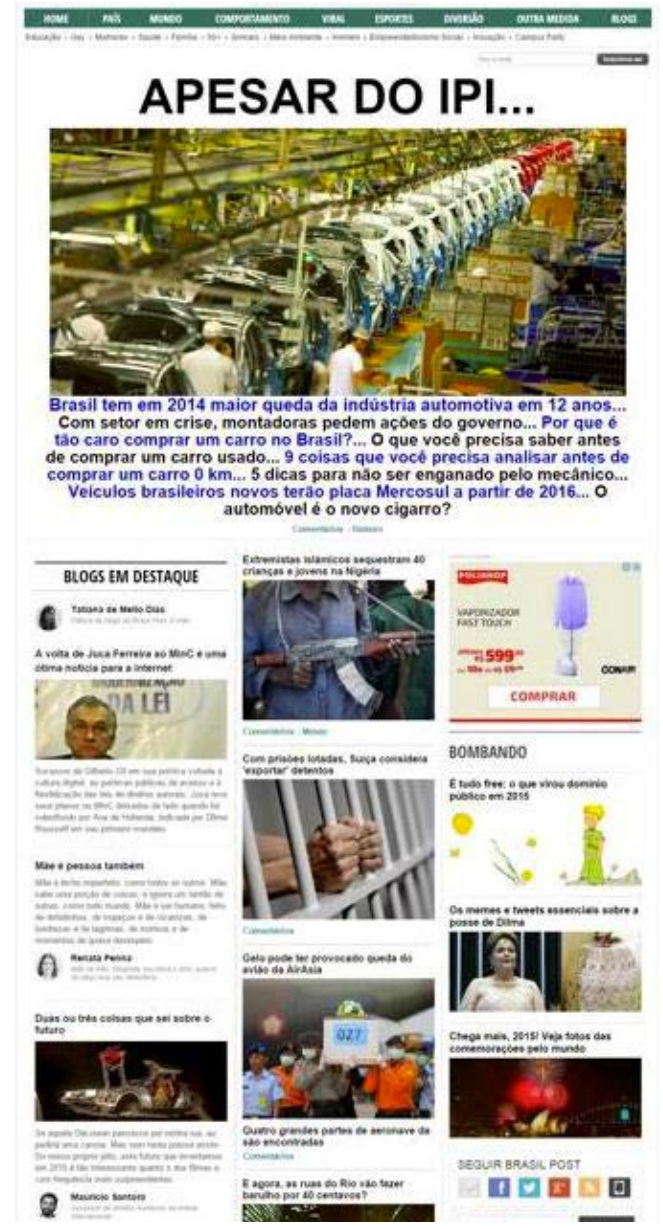

Figura 1: Printscreen da página do BP, janeiro de 2015

Definida a relevância de sua presença, enquanto princípio estruturador da página e do direcionamenfo da leitura no BP, recorremos novamente ao recorte emprestado a Barthes, agora para abordar a segunda forma de articulação entre texto e imagem, designada por ele como etapa, em que aspectos de complementaridade semântica se enunciam entre as duas linguagens, ou os dois discursos - texto verbal e imagem -, que se convertem em duas grandezas de uma totalidade de sentido. Pode se questionar o recurso à divisão de Barthes, quando vários pesquisadores da imagem, com base nos postulados 
do autor francês ou não, complexificaram as dimensões analíticas dos textos visuais ${ }^{3}$. Justifica-se essa escolha pela necessidade de entrada nas camadas simbólicas do texto por um recorte qualquer, mas suficientemente amplo capaz de permitir o estabelecimento de articulações significativas na aparência de forte unidade verbovisual com que se apresenta a página numa primeira visada (Figura 1).

Adotamos, porém, com adaptações os conceitos barthesianos, pois reconhecemos no corpus examinado relações de complementaridade de diversas ordens, que nos permitiram o estabelecimento de uma pequena (e não exaustiva) tipologia de instâncias, que foram assim designadas: a) contextualizadoras b) autossuficientes c) cíclicas d) retratos "flagrantes delitos" e) metonímicas f) baixa figuratividade g) imagens de arquivo.

\section{A) Relações de contextualização}

A articulação definida como contextualizadora pressupõe um estado de abertura semântica da imagem e de um fechamento do conteúdo verbal, com desdobramento/enriquecimento informativo. Não entendemos que se trata de uma mera ancoragem, porque, nesses casos, o texto tanto reduz quanto enriquece os conteúdos da imagem. Em outros termos, a fotografia pode se prestar a várias aberturas, e portanto a vários cenários informativos, mas o sentido específico dado pelo verbal, seja nas manchetes, títulos, legendas ou matérias integrais, pode reduzir uma interpretação mais ampla da imagem, ou de sua eventual ambivalência, ao mesmo passo que pode preencher ausências de especificações como marcações circunstanciais.

Pelo fato de outorgar novos dados de informação ao visto, ampliando suas marcações espaço-temporais, actoriais (tais como protagonistas envolvidos), circunstâncias de ordem política ou cultural, e implicações socioideológicas, o discurso verbal tem o papel de criar um percurso narrativo específico de leitura que poderia ficar menos

\footnotetext{
${ }^{3}$ Entre eles cabe menção a obra de Martine Joly (1994), os estudos de semiótica figurativa e plástica de Algirdas-Julien Greimas (1984) e Jean-Marie Floch (1987), as análises de Vicente Pietroforte (2004) desenvolvidas no Brasil com apoio desta abordagem, os postulados sobre a imagem de Didi-Huberman (2010; 2013), de José de Sousa Martins (2008), no quadro de uma pesquisa sociológica da imagem, de Pepe Baeza (2001), Jorge Pedro Sousa $(2000 ; 2004)$ e Margarita Ledo (1998), sobre o fotojornalismo ou o fotodocumentarismo em particular. De nossa parte, indicamos o artigo Análise e ensino da imagem informativa: aspectos teórico-metodológicos, publicado na revista INTEXTO, da UFRGS, Brasil, no qual postulamos uma perspectiva possível de abordagem da imagem no jornalismo (CAETANO, 2012).
} 
claro ou ambíguo em face da imagem selecionada. Obviamente, ações intencionadas de ambivalência da imagem resultando efeitos de sentido conotativos em certos quadros de predicação informativa podem acontecer, mas esse fenômeno será definido mais adiante. Por ora, queremos indicar o grau de resolução semântica propiciado pelo texto em relação à possível abertura de conteúdos do visual. Usamos a expressão "resolução semântica" emprestada do pesquisador português Antonio Fidalgo (2007), mas na presente ocorrência com uma redução de significado. Para o autor, a resolução acontece no ambiente intermidiático, quando as recorrências de uma informação vão dando maior riqueza informativa ao dado, em clara analogia à resolução de uma imagem que permite melhor visualização de detalhes, enquanto nós estamos empregando sua metáfora no âmbito dos vínculos imagem-textos verbais. O verbal aí especificaria o recorte de leitura da imagem ao mesmo tempo que lhe daria maiores contornos de detalhes contextuais.

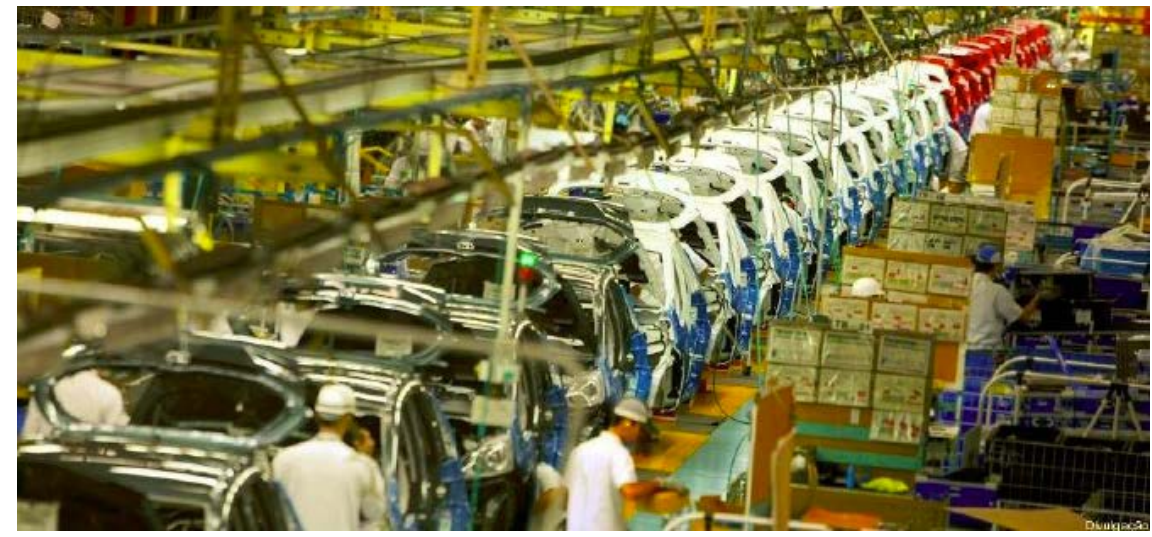

Figura 2: Printscreen BP, janeiro de 2015.

B) Autossuficiência da imagem

Essa condição comporta uma valorização semiótica à imagem, sobretudo a fotográfica, considerando-a competente para expressar, por si só, determinado enunciado (Figura 3). A diferença com respeito às imagens consideradas puramente ilustrativas, é que no contexto analisado elas apresentam um grau informativo suficiente para prescindir do texto verbal, não fosse a necessidade de alguns 
detalhamentos circunstanciais que permitam distingui-la de outra de uma mesma "família" de conteúdos. Por exemplo, em situações de conflito de relevância internacional, há a constante reprodução de imagens que fora de qualquer contexto verbal remetem imediamente ao fato reportado. Por meio desse, porém, o leitor fica a par dos "últimos acontecimentos" no curso do conflito. Um exemplo que ficou marcante no conjunto da segunda prospecção feita no Brasil Post, em janeiro de 2015, foi a imagem recorrente da presidenta Dilma como candidata reeleita. Independente do texto, tendo em vista que esse não apresentava nenhum raciocínio de caráter opinativo, a imagem já preenchia o conteúdo relatado. Esse procedimento implica economia simbólica para o discurso informativo, na medida em que requer pouca competência interpretativa e não imperiosidade da leitura da matéria linguística, além de potencializar atitudes de parada (stoppers) diante da notícia apenas pelo poder de evocação da imagem. Evidentemente, elas requerem o compartilhamento de um mesmo universo referencial, dado pelo contexto sociopolítico, cultural, conjuntural: nos casos empíricos estudados, referiram-se a cenas de filme em cartaz, grandes catástrofes e tragédias, fatos políticos de repercussão nacional e mundial recorrentes.

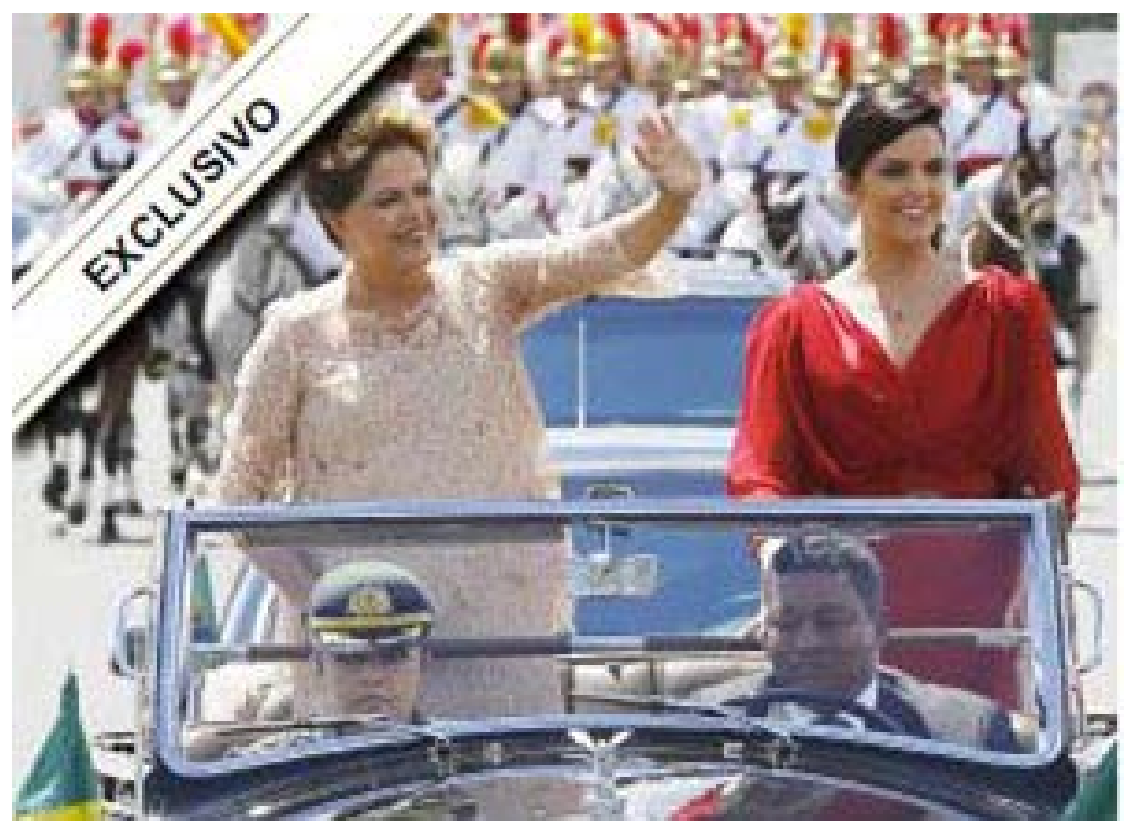

Figura 3: Printscreen BP, janeiro de 2015 


\section{C) Imagens cíclicas}

Subítem talvez da categoria anterior (autossuficientes), esse conceito contempla casos de imagens cristalizadas e que ciclicamente são retomadas como desencadeadores de conotações. Estudos dessas imagens, definidas pelo senso comum como "icônicas" em face do caráter recorrente e universal que suscitam de alusão sempre ao mesmo evento fundacional, apontam não só para o caráter cíclico de sua aparição, mas também ao poder de configuração cíclica que conferem a períodos, épocas, episódios considerados marcantes na história da humanidade ou de uma sociedade ${ }^{4}$. A destruição das Torres Gêmeas, por exemplo, é um desses exemplos, e no corpus estudado ela aparece como traço antecipador de pauta, convertendo-se em "vinheta" para chamadas ao tema do terrorismo.

A par de constituírem formas de economia simbólica na produção da notícia, traço presente nas imagens autossuficientes, ela dotam o texto verbal de um tom opinativo mesmo que este se apresente sob a forma de um dizer objetivo, próprio da configuração noticiosa em sentido estrito. Sabemos que a objetividade do formato notícia é conquistado graças a um modo de enunciar que alça o olhar e a escritura de um observador ao papel de uma voz anônima, coletiva, a despeito de sua perspectiva pessoal. No entanto, as vinhetas e outros recursos de aberturas de emissões - impressas, televisivas ou digitais - configuram-se como molduras do ambiente informativo que virá, antecipando sua estrutura e atmosfera (FONTANILLE, 2005, p.123-160). Qualquer debate sobre terrorismo, conflito no Oriente Médio, judeus e palestinos, mundo árabe, islamismo, e outros similares, serão lidos a partir desse frame (GUMBRECHT, 2006, p. 56-57) do episódio das Torres Gêmeas, portanto com certo tipo de (pre) disposição concernente aos tópicos mencionados.

D) Retratos como "flagrantes delitos"

Essa série, bastante comum no jornalismo político, compreende flagrantes fotográficos (LANDOWSKI, 2007) que se contrapõem às normas de adequação ao retrato oficial, chamando a atenção para aspectos considerados culturalmente ridículos nesse gênero, como boca

4 Verificar tese defendida por Ana Paula da Rosa, sobre as imagens cíclicas, na UNISINOS (ROSA, 2012). 
aberta, olhares semi-fechados, gestos inapropriados a certas circunstâncias, e que, às vezes, colocados em contexto com outros atores e sob um contexto histórico-político podem gerar ou enfatizar sentidos conotativos, sobretudo de ironia. É o caso de personalidades que estão em situação polêmica e são capturados pelo ato fotográfico exatamente no momento em que estão posicionados de costas ou apresentam algum gesto aparentemente desabonador em relação ao outro (figura 4). Trata-se de uma clara herança do jornalismo político de caráter opinativo e indicam um jornalismo tanto voltado a uma perspectiva crítica centrada na imagem, quanto a uma interação lúdica com o leitor, pelo fato de incitá-lo a depreender os efeitos de sentido da foto. $\mathrm{O}$ retrato flagrante se contrapõe à metamorfose (BARTHES, 1982, p. 22) que acontece quando o fotografado percebe a presença do fotógrafo e se antecipa ao momento do registro, preparando-se para a pose.

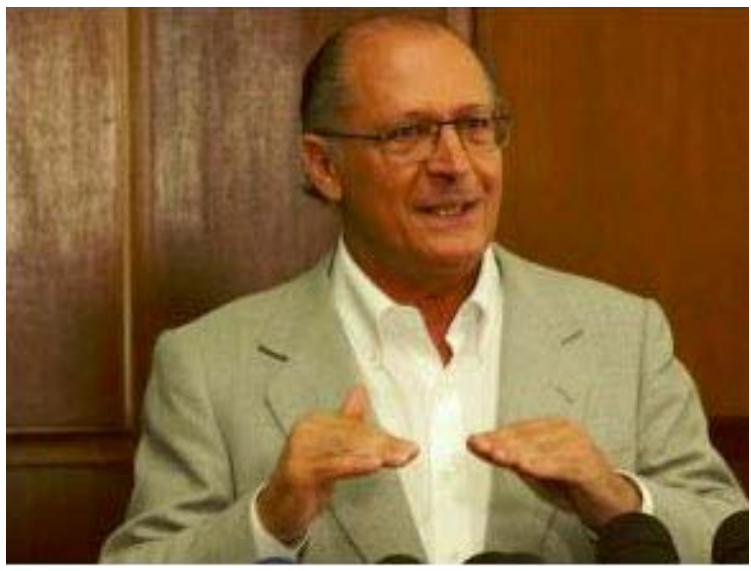

Figura 4: Printscreen BP, novembro de 2014

E) Imagens metonímicas

Reportam-se à totalidade de um fato por meio de recortes de unidades imediatamente associáveis a uma notícia. Requerem igualmente um mesmo universo de referências, tanto em relação aos fatos reportados quanto com respeito aos simbolismos culturais. Implicam economia interpretativa e neutralização de valores polêmicos, na medida em que têm como assentados alguns pressupostos necessários à compreensão da notícia. Em outros termos, não se discute o pressu- 
posto - com base nele é que o sentido do posto está assegurado. As imagens de pessoas portando uma kalashnikov, por exemplo, remetem invariavelmente a uma matéria que vai tratar de terrorismo; fotos de cédulas de dinheiro, mãos escondendo dinheiro, evocam os processos de corrupção política no Brasil (Figura 5). Também nesse caso, a imagem denota um jornalismo mais afeito ao caráter opinativo, que se restringe a expor os fatos no verbal e a axiologizá-los na imagem.

\section{Extremistas islâmicos sequestram 40 crianças e jovens na Nigéria}

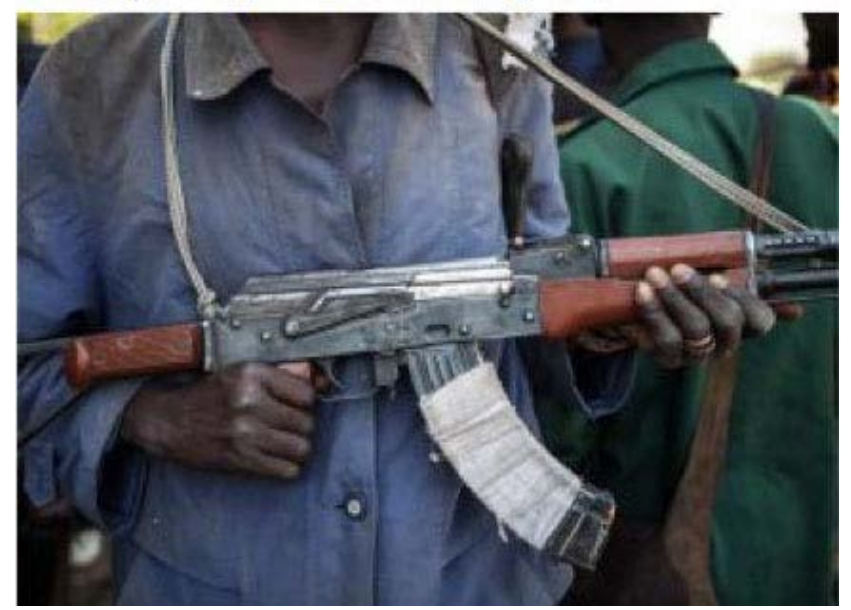

Figura 5: Printscreen BP, janeiro 2015

F) Baixa densidade figurativa

De pouco uso no Brasil Post, assim como no jornalismo em geral, pelo fato de que nesse meio as imagens devem ser imediatamente reconhecidas, servem a propósitos de invisibilidade dos sujeitos, quando a situação assim requer, ou de efeitos estéticos, voltados a uma parada na imagem para sua decifração (figura 6). Por isso, requerem maior competência interpretativa do leitor. Caracterizam-se, em geral, no conjunto analisado, por jogos de claro/escuro, baixo grau de figuratividade, às vezes em preto e branco, imagens borradas, estas últimas determinadas por uma escolha de "não fazer ver" do fotó- 
grafo, como é o caso dos relatos de estupro no campus da USP/SP ou pelo "fazer não ser visto" do objeto apreendido pela câmera, em casos de pessoas que não podem ser fotografadas. O jogo do ver - ser visto, e suas possibilidades combinatórias são fundamentais para a análise dos posicionamentos do jornal e dos recursos estéticos que mobiliza para apresentar a notícia, quando as condições não são favoráveis a uma invasão do jornalista no campo da informação, seja por questões éticas ou por injunções externas (CAETANO \& LEMOS, 2007).

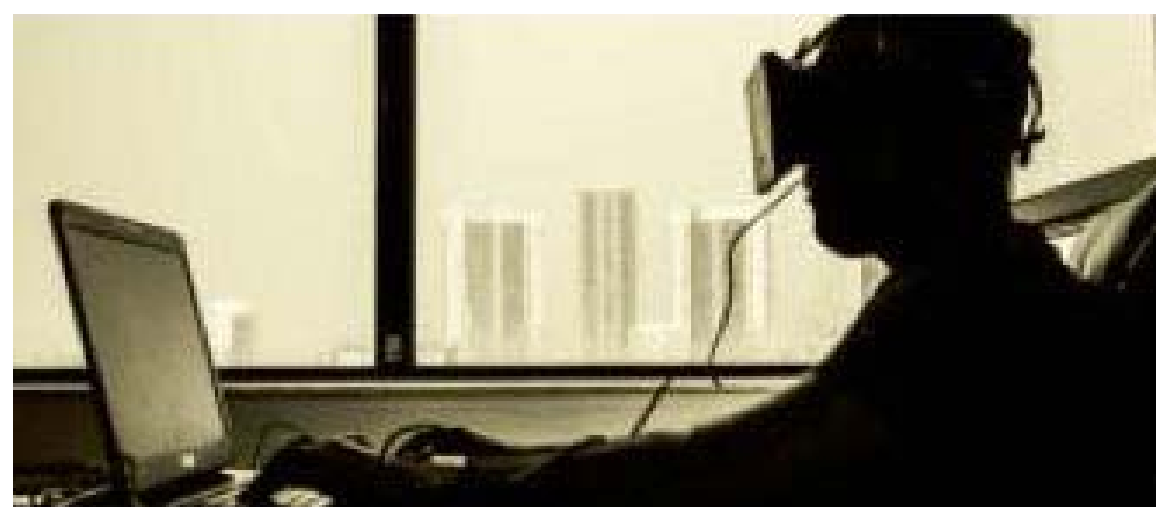

Figura 6: Printscreen BP novembro de 2014

G) Imagens de arquivos históricos

Mais comuns no jornalismo digital, pela facilidade de busca que apresentam e pelo fato de constarem em vários repositórios do ambiente web, as imagens de arquivos, de sentido histórico, entram em vários contextos para suprir falta de material fotográfico ou para ilustrar matérias igualmente desprovidas de atualidade (figura 7). Em reportagens históricas especiais, elas têm uma articulação mais orgânica com as matérias jornalísticas, porque servem como elementos de prova documental, além de unidades de evocação e memória. Exemplos do primeiro tipo foram detectados nos jornais analisados, uma vez que no período de investigação nenhuma reportagem especial foi publicada. 


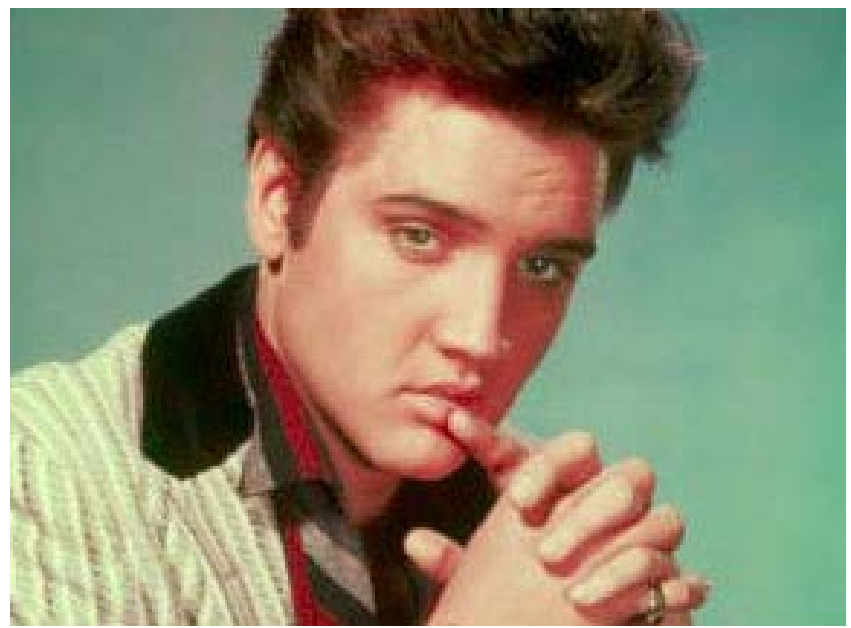

Figura 7: Printscreen BP novembro de 2014

Quando transformadas em números, a categoria que mais aparece nas edições pesquisadas foi a de retratos "flagrante delito", com $38,55 \%$; em seguida, as imagens metonímicas aparecem com $24 \%$; logo após as imagens contextualizadoras somam $14,45 \%$; na sequência aparecem as imagens de arquivo com $7,2 \%$; e depois as autossuficientes com $6,02 \%$. Com $4,8 \%$, as que têm o menor número de imagens são as de Baixa Figuratividade e Cíclicas.

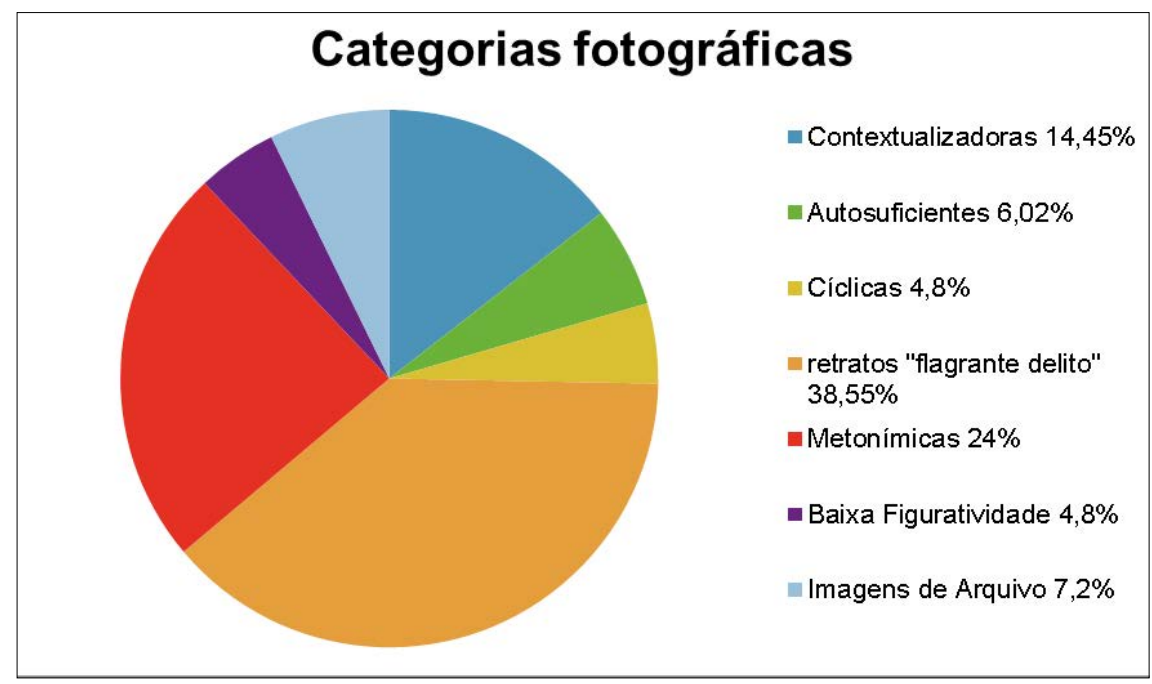

Figura 8 : Tabela criada pelas autoras, 2015 
Com base no levantamento feito, algumas reflexões analíticas podem ser depreendidas, tal como segue:

1. O layout da página de superfície do BP reitera uma forma de organização do material informativo tradicionalmente vinculada a estratégias, já naturalizadas na história da imprensa, de seriedade jornalística, na qual há a oposição entre "sensacionalismo" versus "compromisso com a verdade", tradicionalmente empregada na referência aos jornais impressos. Esse efeito de sentido de verdade está formalizado, do ponto de vista visual, em uma estrutura de pensamento lógico enfatizado pelo contorno nítido das colunas, a distribuição e uso dos espaços e a divisão dos gêneros jornalísticos (opinião, notícia, participação externa, atualizações da rede informativa como um todo, podendo conferir a impressão de domínio ubíquo da informação e do que se discute nas redes sociais).

2. Predominância da fotografia como prova documental, visando a gerar efeito de sentido de realidade e, em última instância, de verdade. Aqui se empregam a relação fazer saber/fazer ver como modos de conhecer e sentir (no sentido de ancoragem) e as relações de complementariedade verbovisual (com maior presença enunciativa). Percebe-se também o uso de formantes cromáticos excessivos - o que denota a influência da publicidade e da TV ocorrida já com o impresso.

O maior percentual de retratos indica que a personificação é centralizadora e, ao contrário de falar sobre as estruturas e processos dialógicos que estão por trás dos fatos, desestimula e inibe o desenvolvimento do conhecimento que cria bases para a participação cívica. $\mathrm{O}$ retrato oficial e o retrato flagrante delito assumem posições de destaque nas edições analisadas. Importante acrescentar, também, que as relações complementares entre texto e imagem configuram-se em modalidades de: desdobramentos, detalhamentos e contextualização de dados, ou de críticas veladas, que se insinuam sob forma irônica ou lúdica (mais comuns nos títulos de fotos). Percebe-se ainda um alto grau de estereotipia nos modos de enunciar visualmente e semanticamente a informação.

3. A creditação autoral rarefeita das imagens, conforme exposto no início deste texto, indicam uma desvalorização autoral do fotojornalismo em favor da valorização da imagem como recurso à disposição do jornalista (prática motivada sobretudo pela reserva de fotos, sem fundo, da rede na era da internet colaborativa). 
4. O perfil apreendido é o de um jornal noticioso, de consumo rápido, voltado a fazer crer na objetividade da informação e na atualização constante de seus dados (embora a média de atualização diária seja de 10 matérias). Desse ponto de vista, não apresenta diferenciais significativos, durante o período observado, em relação a outros jornais/sites de notícias em geral.

Por fim, tendo em vista que tais reflexões constituem pontos de partida para o avanço de uma pesquisa que se desenvolve em rede, consideramos produtiva a colocação de algumas sugestões para as próximas etapas de seu desenvolvimento, as quais poderão futuramente amparar escolhas metodológicas coletivas.

Em primeiro lugar, constata-se como fundamental a abordagem comparativa entre as distintas edições internacionais, e seu jornal-sede norte-americano, conforme prevê o projeto original, pois os dados extraídos dessas outras análises poderão fornecer subsídios mais consistentes e aprofundados sobre o perfil identitário do Huffington Post em geral, e do Brasil Post em particular. Nesse sentido, os vários grupos envolvidos no JADN (Journalisme à l'heure du numérique - Jornalismo na era do digital) já vêm trabalhando com trocas de informações e constituindo grupos internacionais de interesses temáticos.

Preconiza-se ainda a necessidade de um trabalho comparativo com outros jornais online brasileiros, visando à definição do papel e da posição do $B P$ no contexto nacional, com relação a: construção identitária projetada; estratégias de interação com o público; posicionamento ideológico-crítico em relação não apenas à informação, mas também à própria imprensa nacional; maior exploração das potencialidades do digital ou de uma elaboração claramente estruturada no ambiente de convergência, mobilidade e contexto em multiplataformas (não detectado no material analisado) ${ }^{5}$.

Com essas perspectivas, a investigação conjunta permitirá aportes mais significativos tanto para o papel das imagens no contexto digital, como para uma abordagem comparativa entre as diferentes edições de um mesmo empreendimento jornalístico, e de suas adaptações aos contextos multimidiáticos e de multiplataformas, fase atual da presente pesquisa.

5 Trabalho que vem sendo desenvolvido em atividade de Iniciação Científica pelo aluno Thales Marques (UTP) sob orientação da Profa. Dra. Kati Caetano (PPGCom/UTP), analisando tais categorias comparativamente entre o Brasil Post, o Vice News Brasil e a edição brasileira do El Pais Brasil. 


\section{Referências}

BAEZA, Pepe. Por una función crítica de la fotografía de prensa. Barcelona: Gustavo Gili, 2001.

BARTHES, Roland. Rhétorique de l'image. In: Communications, 4, 1964. p. 40-51.

A Câmara Clara. São Paulo: Editora 34, 1982. p.22.

CAETANO, Kati. Análise e ensino da imagem informativa: aspectos teórico-metodológicos. Revista Intexto, UFRGS, v. n. 26, 2012, p. 1-17.

CAETANO, Kati; LEMOS, Anuschka. À margem do olhar, à margem da imagem: regimes de visibilidade na fotografia documental. Razón y palabra . México: Razón y palabra, vol. 17, 2007, p. 1-18.

DIDI-HUBERMAN, Georges. Diante da imagem. São Paulo : Editora $34,2013$.

. O que vemos, o que nos olha. São Paulo: Editora 34, 2010.

FIDALGO, António. A resolução semântica no jornalismo online. In: BARBOSA, S. (Org.). Jornalismo digital de terceira geração. Coleção Estudos em Comunicação. Covilhã: Livros Labcom, 2007.

FLOCH, J.-M. Les formes de l'empreinte: Brandt, Cartier-Bresson, Doisneau, Stieglitz, Strand. Périgueux, Pierre Fanlac, 1986.

. Identités visuelles. Paris: Presses Universitaires de France, 1995.

. Semiótica plástica e linguagem publicitária. Significação. Revista Brasileira de Semiótica. Araraquara: Centro de Estudos Semióticos, 6, jan.1987, 29-50.

FONTANILLE, Jacques. Significação e visualidade: exercícios práticos. Porto Alegre: Sulina, 2005. 
GREIMAS, Algirdas-Julien. Semiótica figurativa e semiótica plástica. Significação. Revista Brasileira de Semiótica. Araraquara: Centro de Estudos Semióticos, 4, 1984, 18-46.

GREIMAS, Algirdas-Julien \& COURTÉS, J. Dicionário de semiótica. São Paulo: Cultrix, 1979.

GUMBRECHT, H.-U. Pequenas crises. Experiência estética nos mundos cotidianos. In : GUIMARÃES, C.; LEAL, B.S. \& MENDONÇA, C. C. (orgs.) Comunicação e experiência estética. Belo Horizonte: Editora UFMG, 2006, p. 50 - 63.

JOLY, Martine. Introduction à l'analyse de l'image. Paris: Éditions Nathan, 1994.

LANDOWSKI, E. Flagrants délits et portraits. In: SEMPRINI, A. (org.) Analyser la communication II. Regards sociosémiotiques. Paris : L'Harmattan, 2007, pp. 89-126. (versão publicada no Brasil : Flagrantes delitos e retratos. Galáxia, PUCSP/Brasil, v. 4, n. 8, 2007).

. Les interactions risquées. Nouveaux Actes Semiotiques. Limoges: Pulim, 2005a, v. 101,102,103.

. Aquém ou além das estratégias, a presença contagiosa. Documentos de Estudo. Centro de Pesquisas Sociossemióticas, São Paulo: PUC, Edições CPC, 2005b.

LEDO, Margarida. Documentalismo fotográfico. Éxodos e identidad. Madrid: Catedra, 1998.

MARTINS, José de Sousa. A epifania dos pobres da terra. In: MAMMI, L. \& SCHWARCZ, L. M. (Orgs.). 8 X Fotografia: ensaios. São Paulo: Companhia das Letras, 2008, pp. 133-171.

PIETROFORTE, Antonio Vicente. Semiótica visual: os percursos do olhar. São Paulo: Contexto, 2004. 
ROSA, Ana Paula da. Imagens totens: a fixação de símbolos nos processos de midiatização. 2012. Tese (Doutorado em Ciências da Comunicação) - Universidade do Vale do Rio dos Sinos.

SOUSA, Jorge Pedro. Uma história crítica do fotojornalismo ocidental. Chapecó: Grifos, 2000.

. Fotojornalismo: introdução à história, às técnicas e à linguagem da fotografia na imprensa. Florianópolis: Letras Contemporâneas, 2004.

TÜRCKE, Christoph. Sociedade excitada: filosofia da sensação. Campinas/SP: Editora da UNICAMP, 2010. 